\title{
AKTIVASI KEMANDIRIAN SISWA PADA MODEL PEMBELAJARAN KOOPERATIF TIPE JIGSAW DALAM MATA PELAJARAN PAI DI KELAS VIII-A1 PUTRA SMP-IT RAUDHATUL ULUM SAKATIGA
}

\author{
Abdillah Shafrianto \\ Sekolah Tinggi Ilmu Tarbiyah Raudhatul Ulum Sakatiga \\ Email: abdillah shafrianto20@gmail.com
}

\begin{abstract}
Abstrak
Pembelajaran merupakan sebuah usaha yang dilakukan oleh seorang guru untuk membelajarkan siswa di dalam proses belajar atau secara sederhananya adalah guru mengajar dan siswa belajar. Dengan pembelajaran yang baik dan terarah akan menumbuhkan kemandirian siswa, akan tetapi saat ini kemandirian siswa di VIII-A1 Putra SMP-IT Raudhatul Ulum Sakatiga masih dirasakan rendah sehingga model pembelajaran kooperatif tipe jigsaw yang digunakan oleh guru PAI diharapkan dapat menumbuhkan kemandirian (emosi, intelektual dan sosial) di kelas. Jenis penelitian bersifat kualitatif dengan pendekatan deskriptif. Unuk teknik pengumpulan data menggunakan: observasi menggunakan observasi partisipasi yang bersifat pasif, observasi Wawancara menggunakan wawancara tidak terstruktur kepada informan. Dokumentasi digunakan untuk menuliskan apa yang benar-benar terjadi di lapangan dan mengabadikan proses kegiatan model pembelajaran kooperatif tipe jigsaw. Triangulasi digunakan sebagai pembanding antara data observasi terhadap data wawancara dan data dokumentasi yang berkaitan.

Berdasarkan data yang diperoleh dan kemudian dianalisis, maka penelitian ini adalah: Pada pelaksanaan model pembelajaran kooperatif tipe jigsaw di kelas VIII-A1 adalah sangat baik dengan digunakannya jigsaw. Untuk kemandirian siswa berupa kemandirian emosi, intelektual dan sosial siswa di kelas VIII-A1 sangat baik, dikarenakan siswa merasa senang, siswa juga mengerti dengan materi pembelajaran dan interaksi sosial juga terjalin dengan sangat baik. Faktor yang menjadi pendukung berupa penghargaan, pujian, motivasi dan kontribusi anggota. Kemudian adalah pemberian informasi, arahan materi yang baik dan keakraban antara guru dengan siswa.Selanjutnya persiapan materi pembelajaran oleh guru dengan baik, pengelompokan siswa yang bersifat heterogen dan rasa empati terhadap sesama.
\end{abstract}

Kata Kunci: Model Pembelajaran, Kooperatif, Jigsaw, Kemandirian

\section{Pendahuluan}

Pendidikan merupakan suatu hal yang sangat pokok dan sangat mendasar dalam kehidupan manusia, karena hanya dengan adanya pendidikan yang baik maka dapat membedakan manusia dengan makhluk lainnya.Pendidikan juga berguna untuk mengarahkan manusia agar menjadi manusia yang sesungguhnya. Secara sederhana pendidikan berarti perbuatan atau proses perbuatan untuk memperoleh pengetahuan. (Muhibbin Syah, 2008:10) Pendidikan merupakan produk kebudayaan manusia, dimana kegiatan pendidikan dilakukan dalam upaya mempertahankan, melanjutkan hidup dan kehidupan manusia. (Ara Hidayat, 
Aktivasi Kemandirian Siswa Pada Model Pembelajaran Kooperatif Tipe Jigsaw Dalam Mata Pelajaran PAI di Kelas VIII-A1 Putra SMP IT Raudhatul Ulum Sakatiga

Abdillah Shafrianto

2012:30) Pendidikan juga dapat berarti memberikan bantuan berupa bimbingan dan pengarahan kepada peserta didik, salah satunya adalah dengan proses belajar melalui lembaga pendidikan yang ada pada saat ini seperti sekolah, madrasah dan pesantren.

Fungsi utama sekolah ialah pendidikan intelektual, yakni "mengisi otak" anak dengan berbagai macam pengetahuan. (Nasution, 2014:13) Penerimaan berbagai macam pengetahuan yang diberikan guru kepada siswa disebut dengan istilah belajar. Secara umum belajar dapat dipahami sebagai tahapan perubahan seluruh tingkah laku individu yang relatif dan menetap sebagai hasil pengalaman dan interaksi dengan lingkungan yang melibatkan proses kognitif (Muhibbin Syah, 2013:68) Menurut pengertian secara psikologi, belajar merupakan suatu proses perubahan tingkah laku sebagai hasil dari interaksi dengan lingkungannya dalam memenuhi kebutuhan hidupnya. Perubahan-perubahan tersebut akan nyata dalam seluruh aspek tingkah laku. (Slameto, 2013:2) Berdasarkan beberapa uraian definisi belajar maka dapat dikatakan bahwa, belajar merupakan perubahan yang meliputi segala aspek yang ada pada diri individu atau siswa ketika sedang mengalami proses belajar menggunakan panca inderanya.

Pada sebuah proses pembelajaran, salah satu faktor yang sangat penting untuk membantu dan membimbing siswa adalah guru, karena guru merupakan pendidik professional dan secara implisit ia telah merelakan dirinya menerima dan memikul sebagian tanggung jawab pendidikan yang terpikul di pundak orang tua.(Zakiah Darajat, 2011:39) Ketika guru memberikan materi pembelajaran, guru tentunya harus memperhatikan siswa, karena siswa merupakan pribadi yang kompleks.Pada saat proses belajar sedang berlangsung, seorang pendidik harus mempunyai pola atau model pembelajaran jika ingin proses belajar tersebut berjalan dengan hasil yang baik, karena belajar bukan hanya memberikan ilmu pengetahuan (transfer of knowledge) kepada para siswa, akan tetapi yang diinginkan guru adalah bagaimana siswa tersebut bisa menjadi mandiri baik di dalam proses pembelajaran di kelas dan juga di dalam keseharian, oleh karena itu peran serta guru sangat besar dalam membimbing para peserta didik atau siswa.

Maksud kemandirian pada peserta didik di sini adalah, dengan adanya kemandirian para siswa belajar dan berlatih untuk membuat rencana, memilih alternatif, membuat keputusan, bertindak dengan keputusan sendiri atau bersama serta bertanggung jawab atas segala sesuatu yang dikerjakan. Untuk mengatasi halhal yang berkaitan dengan kemandirian siswa, guru di dalam proses pembelajaran salah satunya adalah dengan menggunakan model pembelajaran yang bersifat kelompok atau biasa disebut dengan pembelajaran kooperatif (cooperative learning). Berkenaan dengan hal tersebut guru PAI di SMP-IT Raudhatul Ulum, yaitu Muhammad Altop mengatakan bahwa: "Untuk kemandirian siswa di kelas pada proses pembelajaran masih kurang, karena masih ada siswa yang belum mampu memahami dan menguasai materi pelajaran. Mereka belum mampu menguasai dan 
P-ISSN : 2541-3686

memahami materi mungkin dikarenakan segan untuk bertanya kembali kepada guru atau ada aspek lain yang mempengaruhi mereka".

Adapun indikator kemandirian pada diri siswa adalah sebagai berikut; Pertama, adanya hasrat yang kuat untuk belajar.Kedua, mampu mengambil keputusan dan inisiatif untuk menghadapi masalah.Ketiga, bertanggung jawab atas apa yang dilakukan. Keempat, percaya diri dan melaksanakan tugas-tugasnya secara mandiri. (Enung Fatimah, 2010:141) Kelima, mampu menyesuaikan diri dengan lingkungan. (Negoro Suratino,2008:17) Kelima indikator kemandirian yang telah diuraikan tersebut masih sedikit yang ada pada diri siswa kelas VIII-A1, hal tersebut juga senada dengan hasil wawancara yang dikatakan guru PAI bahwa untuk kemandirian siswa masih kurang.Adapun alasan kemandirian siswa masih dirasakan kurang dikarenakan, "seperti kurangnya guru dalam memahami model pembelajaran yang akan diterapkan di kelas, kurang terstrukturnya dalam menerapkan model pembelajaran dan gaya guru dalam memberikan materi dari model pembelajaran".

Untuk mengatasi masalah yang telah diuraikan, maka model pembelajaran kooperatif tipe jigsaw diharapkan dapat menjadi solusi yang tepat untuk menumbuhkan kemandirian siswa di kelas

\section{Landasan Teori}

a. Model Pembelajaran Kooperatif Tipe Jigsaw

1) Definisi Model Pembelajaran Kooperatif Tipe Jigsaw

Jigsaw merupakan model pembelajaran yang didesain untuk meningkatkan rasa tanggung jawab siswa terhadap pembelajarannya sendiri dan juga pembelajaran orang lain. Siswa tidak hanya mempelajari materi yang diberikan, tetapi mereka juga harus siap memberikan dan mengajarkan materi tersebut kepada kelompoknya. (Imas Kuniasih,2015:24) Arti jigsaw dalam bahasa Inggris adalah gergaji ukir dan ada juga yang menyebutnya dengan istilah puzzle, yaitu sebuah teka-teki menyusun potongan gambar. Pembelajaran kooperatif tipe jigsaw ini mengambil pola cara bekerja sebuah gergaji (zig-zag), yaitu siswa melakukan suatu kegiatan belajar dengan cara bekerja sama dengan siswa lain untuk mencapai tujuan bersama. (Rusman,2014:217)

Berdasarkan uraian di atas maka dapat dikatakan bahwa, jigsaw merupakan salah satu tipe dari model pembelajaran kooperatif, pada jigsaw siswa di dalam kelompok dapat menyumbangkan informasi, pengalaman, ide, sikap, pendapat, kemampuan dan keterampilan yang dimiliki, untuk secara bersama-sama saling meningkatkan pemahaman seluruh anggota. Jigsaw juga dapat dipahami sebagai model pembelajaran kooperatif yang terdiri dari beberapa anggota dalam satu kelompok yang bertanggung jawab atas penguasaan bagian materi belajar dan mampu mengajarkan materi tersebut kepada anggota lain dalam kelompoknya. 
Aktivasi Kemandirian Siswa Pada Model Pembelajaran Kooperatif Tipe Jigsaw Dalam Mata Pelajaran PAI di Kelas VIII-A1 Putra SMP IT Raudhatul Ulum Sakatiga

\section{Abdillah Shafrianto}

2) Langkah-langkah Pelaksanaan Jigsaw

Pada sebuah kelompok di dalam jigsaw, kelompok dibuat menjadi dua bagian yaitu kelompok asal (home group) dan kelompok ahli (expert group). Pada jigsaw, siswa bekerja kelompok selama dua kali, yakni dalam kelompok mereka sendiri dan dalam kelompok ahli.Kelompok ahli merupakan kelompok yang berasal dari kelompok asal yang berbeda, yang ditugaskan untuk mempelajari dan menyelesaikan tugas-tugas yang berhubungan dengan topiknya untuk kemudian dijelaskan kepada anggota kelompok asal.

Kelompok ahli juga berfungsi sebagai tim yang berdiskusi dan mencari cara terbaik bagaimana menjelaskan bagian informasi dari materi pembelajaran kepada teman-teman satu kelompoknya semula. Setelah berdiskusi, semua siswa di dalam kelompok ahli (expert group) kembali kepada kelompok asalnya dan mulai menjelaskan bagian dari informasi kepada teman-teman satu kelompoknya.

\section{b. Kemandirian Siswa}

Kemandirian berasal dari kata "diri" yang mendapat awalan "ke" dan akhiran "an" yang kemudian membentuk suatu keadaan atau kata benda. (Muhammad Ali,2014:109) Selain itu kemandirian juga berasal dari kata mandiri yang diartikan sebagai sikap dan perilaku yang tidak mudah tergantung kepada orang lain dalam menyelesaikan tugas-tugas.(Husamah,2015:233) Morrison mengatakan bahwa kemandirian adalah, "kemampuan untuk mengerjakan tugas sendiri, menjaga diri sendiri dan memulai kegiatan tanpa harus selalu diberi tahu apa yang harus dilakukan". (Morrison George,2012:228)

Kemandirian di sini merupakan kemampuan siswa dalam untuk melakukan, memikirkan dan merasakan segala sesuatu dalam rangka mengatasi masalah, bersaing, mengerjakan tugas dan mengambil keputusan dengan tingkat kepercayaan diri yang tinggi. Selain itu kemandirian tidak hadir dengan sendirinya pada siswa atau peserta didik, kemandirian itu dibangun dengan cara-cara yang terstruktur dan berkesinambungan serta pembiasaan baik dilakukan oleh orangtua di rumah ataupun guru di sekolah.

\section{c. Macam-Macam Kemandirian Siswa}

Robert Havigust yang dikutip oleh Desmita membedakan kemandirian atas empat bentuk kemandirian, yaitu: "Pertama, kemandirian emosi, yaitu kemampuan mengontrol emosi sendiri dan tidak tergantungnya kebutuhan emosi pada orang lain. Kedua, kemandirian ekonomi, yaitu kemampuan mengatur ekonomi sendiri dan tidak tergantungnya kebutuhan ekonomi pada orang lain. Ketiga, kemandirian intelektual, yaitu kemampuan untuk mengatasi berbagai masalah yang dihadapi.Keempat, kemandirian sosial, yaitu kemampuan untuk mengadakan interaksi dengan orang lain dan tidak tergantung pada aksi orang lain". (Desmita,2014:186) 
Berdasarkan uraian-uraian kemandirian tentang emosi, intelektual dan sosial yang telah dikemukakan dapat disimpulkan bahwa, kemandirian emosi dalam proses pembelajaran adalah rasa senang ataupun tidak yang dialami oleh siswa. Kemandirian intelektual adalah bagaimana siswa menyerap atau memahami materi dari suatu pembahasan yang dijelaskan oleh guru, sedangkan kemandirian sosial adalah cara siswa dalam berinteraksi kepada sesama teman-temannya pada saat proses pembelajaran sedang berlangsung, interaksi ini dimaksudkan bagaimana siswa saling memberi masukan kepada yang lainnya tentang isi dari materi pembahasan.

\section{Metode Penelitian}

a. Jenis dan Pendekatan Penelitian

Adapun penelitian yang peneliti lakukan ditinjau dari tempatnya merupakan penelitian lapangan (field research) yang langsung dilaksanakan dalam kehidupan sebenarnya di lingkungan sekolah yang menggambarkan keadaan yang ada pada subjek penelitian, sedangkan untuk jenisnya penelitian ini adalah penelitian kualitatif. Penelitian kualitatif merupakan penelitian yang bermaksud untuk memahami fenomena tentang apa yang dialami oleh subjek penelitian misalnya perilaku, persepsi, motivasi, tindakan dan lain-lain. (Lexy Moleong,2014:6)

Adapun pendekatan yang digunakan di dalam penelitian ini adalah pendekatan deskriptif kualitatif. Penelitian deskriptif merupakan penelitian yang dimaksudkan untuk mengumpulkan informasi mengenai gejala-gejala yang ada, yaitu keadaan gejala menurut apa adanya saat penelitian (Suharsimi Arikunto,2010:234) Sedangkan kualitatif adalah penelitian yang analisis isi lebih penting daripada frekuensi atau bilangan. (Nana Sudjana, 2012:129) Berdasarkan pendekatan deskriptif kualitatif, maka peneliti berharap dapat mengumpulkan informasi dari kemandirian siswa di dalam proses pembelajaran yang nantinya pada penelitian ini akan diuraikan dengan analisis yang bersifat naratif.

\section{b. Satuan Kajian (Unit of Analysis)}

Satuan kajian merupakan hal-hal yang ditetapkan dalam rancangan penelitian, berisi tentang penentuan sampel, besarnya dan strategi sampling. (Lexy Moleong,2014:225) Selain itu juga, unit analisis berarti sesuatu yang berdasarkan tujuannya/peraturan tertentu dijadikan suatu kesatuan yang karakteristiknya akan diukur. (Sedamayanti,2011:71) Dalam penelitian ini peneliti tidak menggunakan populasi dikarenakan penelitian ini bersifat kualitatif, tetapi menggunakan istilah social situation atau situasi sosial yang terdiri dari tiga elemen yaitu tempat (place), pelaku (actors) dan aktivitas (activity). (Sugiyono,2013:215) Adapun social situation (situasi sosial) dalam penelitian ini adalah sebagai berikut:

1) Place atau tempat, dalam penelitian ini adalah SMP-IT Raudhatul Ulum Sakatiga 
Aktivasi Kemandirian Siswa Pada Model Pembelajaran Kooperatif Tipe Jigsaw Dalam Mata Pelajaran PAI di Kelas VIII-A1 Putra SMP IT Raudhatul Ulum Sakatiga

Abdillah Shafrianto

2) Actors atau pelaku, dalam penelitian ini adalah guru PAI yang mengajar di kelas VIII A1 putra dan siswa kelas VIII-A1 putra SMP-IT Raudhatul Ulum Sakatiga

3) Activity atau aktivitasnya, dalam hal ini adalah kemandirian siswa kelas VIIIA1 putra SMP-IT Raudhatul Ulum Sakatiga di dalam model pembelajaran kooperatif tipe jigsaw.

Pada penelitian ini, sampel dalam penelitian kualitatif bukan dinamakan responden, tetapi sebagai nara sumber, atau partisipan, informan, teman dan guru. (Sugiyono,2013:216) Informan adalah orang yang dimanfaatkan untuk memberikan informasi tentang situasi dan kondisi latar penelitian. (Moleong,2014:132) Di dalam penelitian ini teknik pengambilan sampelnya peneliti menggunakan purposive sampling, sampling yang purposive adalah sampel yang dipilih dengan cermat hingga relevan dengan desain penelitian. (Nasution,2012:98) Purposive sampling merupakan teknik pengambilan sampel sumber data dengan pertimbangan tertentu. (Sugiyono,2013:218)

Adapun maksud dari pertimbangan tertentu dari teknik pengambilan sampel yang digunakan di dalam penelitian ini adalah informan yang ingin diteliti memang benar-benar memberikan data seperti apa yang diharapkan oleh peneliti, selain itu juga informan tersebut dianggap lebih mengetahui tentang apa yang diteliti dan memudahkan peneliti menjelajahi situasi sosial yang diteliti. Informan di dalam penelitian ini adalah guru PAI SMP-IT Raudhatul Ulum Sakatiga yang mengajar di kelas VIII-A1 putra dan siswa kelas VIII-A1 putra SMP-IT Raudhatul Ulum Sakatiga, adapun siswa kelas VIII-A1 putra SMP-IT Raudhatul UlumSakatiga berjumlah 17 orang.

\section{Hasil Temuan}

Pada bagian ini dipaparkan hasil data yang diperoleh dan dijelaskan secara ringkas mengenai aktivasi kemandirian siswa pada model pembelajaran kooperatif tipe jigsaw dikelas VIII-A1 sebagai berikut:

a. Pelaksanaan Model Pembelajaran Kooperatif Tipe Jigsaw

Berdasarkan data yang diperoleh melalui observasi dan wawancara, kemudian data tersebut diproses dengan menggunakan triangulasi, maka diperoleh kesimpulan bahwa pada pelaksanaan model pembelajaran kooperatif tipe jigsaw yang dilakukan di kelas VIII-A1 SMP-IT Raudhatul Ulum Sakatiga sangat baik dengan digunakannya model pembelajaran tersebut. Adapun hasil observasi yang peneliti lakukan adalah sebagai berikut: "selama peneliti berada di dalam lingkungan penelitian, peneliti melihat guru PAI dalam melaksanakan model pembelajaran kooperatif tipe jigsaw kepada siswa tidak menemukan masalah yang berarti. Hal ini disebabkan guru PAI yang mengajar di kelas tersebut, telah mengetahui karakteristik setiap siswa di kelas VIII-A1 putra". 
Selain itu peneliti melihat temuan atas perilaku siswa yang berada di kelas ketika diberi penjelasan materi oleh guru PAI. Adapun temuan tersebut berupa, "ketika siswa ketika diberi penjelasan oleh guru, sangat antusias dalam mendengarkan penjelasan materi yang disampaikan.Setelah penjelasan atas materi telah selesai, selanjutnya guru memberikan pertanyaan seputar materi yang telah diberikan kepada siswa. Disini terlihat ada beberapa siswa yang bisa menjawab pertanyaan yang diberikan oleh guru dan juga ada yang tidak bisa menjawab, bagi siswa yang dirasakan kurang bisa dalam hal menjawab pertanyaan maka guru yang bersangkutan memberikan bantuan kepada siswa dan atas dasar tersebut dapat dikatakan bahwa siswa terlibat secara aktif dalam proses pembelajaran dikelas, selain itu juga guru terampil dalam memberi bimbingan dan bantuan kepada siswa dalam mata pelajaran yang diberikan". Untuk wawancara kepada siswa VIII-A1 adalah sebagai berikut:

Musyafa Ahmad Indrakari mengatakan bahwa, "menurut saya ustadz Altop galak, akan tetapi sifatnya menyenangkan dalam menyampaikan materi".Muhammad Frans Dewa Lanang mengatakan bahwa, "terkadang ustadznya cepat dalam menjelaskan materi bagi saya, akan tetapi ustadznya menyenangkan".Andra Joevanka Rahmatullah mengatakan bahwa, "menurut saya materinya mudah dipahami ketika beliau sampaikan dan juga terkadang beliau sisipkan candaan.Muhammad Rajab mengatakan bahwa, "gurunya menyampaikan materi bagi saya menyenangkan, walau terkadang suka marah jika kami tidak memperhatikan apa yang disampaikan".

Sedangkan untuk hasil wawancara kepada guru PAI adalah sebagai berikut: "Untuk kemandirian peserta didik menurut saya sudah cukup baik, bahkan akan sangat baik apabila peserta didik diarahkan secara terus menerus dalam melakukan diskusi baik kepada guru dan teman-temannya". Dengan demikian keterlibatan guru dalam proses belajar mengajar semakin berkurang, dalam arti guru menjadi pusat kegiatan di kelas. Guru disini hanya berperan sebagai fasilitator yang mengarahkan dan memotivasi siswa untuk belajar mandiri serta menumbuhkan rasa tanggung jawab yang kemudian membuat siswa akan merasa senang berdiskusi tentang materi pelajaran pada kelompoknya.

\section{b. Kemandirian Siswa di Dalam Proses Pembelajaran}

\section{1) Kemandirian Emosi}

Kemandirian emosi pada hal ini merupakan kemampuan siswa dalam mengatur perasaan, baik perasaan suka atau senang terhadap materi pelajaran atau lingkungan pada proses pembelajaran.Berdasarkan hasil observasi di kelas VIII-A1 putra SMP-IT Raudhatul Ulum Sakatiga, "emosi siswa yang peneliti lihat di kelas adalah para siswa merasa senang dengan digunakannya pembelajaran kooperatif tipe jigsaw.Para siswa merasa senang dikarenakan bisa bertanya kepada temantemannya jika tidak mengerti dengan materi pembahasan atau ada hal yang 
Aktivasi Kemandirian Siswa Pada Model Pembelajaran Kooperatif Tipe Jigsaw Dalam Mata Pelajaran PAI di Kelas VIII-A1 Putra SMP IT Raudhatul Ulum Sakatiga

Abdillah Shafrianto

dirasakan aneh.Perasaan senang siswa juga berdasarkan pada suasana kelas yang penuh dengan persaudaraan dan persahabatan, serta suasana kelas juga bersifat humoris. Selain itu juga, siswa terlihat sangat antusias dalam memperhatikan kelompok lain ketika sedang memberikan penjelasan materi".

Adapun hasil wawancara peneliti dengan para siswa tersebut antara lain sebagai berikut:

Menurut siswa kelas VIII-A1 SMP-IT Raudhatul Ulum Sakatiga yang bernama

M. Iqbal Romzy menyatakan bahwa, "pelajaran dalam bentuk kelompok itu lebih mudah atau enak, misalnya ketika diberi pertanyaan dan tidak tahu maka bisa bertanya kepada teman". Selain itu, M. Frans Dewa Lanang bahwa, "tidak menjadi ngantuk dan juga bisa mengeluarkan pendapat walau berbeda"

Sedangkan menurut guru PAI yang mengajar di kelas VIII-A1 putra mengatakan bahwa;

"Menurut saya para peserta didik sebagian besar senang dan sangat antusias dengan menggunakan model pembelajaran kooperatif tipe jigsaw, dikarenakan dengan menggunakan model pembelajaran ini peserta didik semakin percaya diri".Selain itu juga, "menurut guru PAI tersebut, perasaan siswa senang ketika menggunakan model pembelajaran kooperatif tipe jigsaw dikarenakan peserta didik dapat bertukar fikiran, ide dan dapat saling memberikan informasi".

Dengan demikian, berdasarkan hasil observasi peneliti serta wawancara terhadap guru PAI dan siswa kelas VIII-A1 putra yang telah diuraikan di atas, maka dapat dikatakan bahwa emosi yang ada pada siswa kelas VIII-A1 putra SMP-IT Raudhatul Ulum Sakatiga adalah bersifat senang atau gembira dengan adanya pembelajaran kooperatif tipe jigsaw di kelas. Hal tersebut mengandung arti bahwa mereka telah melakukan perubahan dan pembangunan interaksi antar para siswa baik dalam kelompok maupun individu. Adapun yang dapat membuat atau mendorong siswa memperoleh dan mengatur perasaan di dalam pembelajaran kooperatif adalah motif siswa itu sendiri yang disandarkan pada hal bahwa mereka bisa membantu dan memberikan kontribusi terhadap kelompoknya dan kelompok yang lain. Selain hal tersebut juga, secara tidak langsung siswa yang lain juga berperan serta dalam mengolah emosi teman-temannya dengan memberikan masukan-masukan, maupun membantu agar siswa yang lain menjadi berani dalam mengemukakan pendapatnya.

\section{2) Kemandirian Intelektual}

Kemandirian intelektual atau inteligensi merupakan upaya siswa dalam mengatur dirinya untuk berfikir dan tindakan secara terarah.Berdasarkan pengamatan yang peneliti lakukan di kelas VIII-A1 putra SMP-IT Raudhatul UlumSakatiga, "peneliti melihat bahwa kecerdasan siswa terlihat cukup baik.Hal tersebut berdasarkan, ketika ada kelompok yang bertanya kepada kelompok lain, 
Volume 2 Nomor 1 Edisi Juni 2017

P-ISSN : 2541-3686

maka kelompok yang ditanya tersebut memberikan jawaban yang tepat". Menurut guru PAI yang mengajar di kelas VIII-A1 putra mengatakan bahwa;

"Peserta didik faham dan mengerti dengan materi yang dibahas, dikarenakan peserta didik di arahkan dan dijelaskan terlebih dahulu sebelum memulai model pembelajaran kooperatif tipe jigsaw. Siswa juga banyak mencari sumber referensi ke perpustakaan dan media lainnya, sehingga antusias siswa dalam proses pembelajaran ini sangat menyenangkan. Selain daripada itu juga, yang dilakukan siswa jika tidak mengerti dengan materi maka kebanyakan dari peserta didik adalah bertanya dengan teman di kelompoknya, biasanya siswa tersebut bertanya kepada teman yang berasal dari kelompok ahli dan juga menyuruh temannya tersebut untuk bertanya kepada guru jika temannya juga belum bisa memberikan solusi".

Adapun pemahaman siswa terhadap materi pembelajaran yang dijelaskan oleh temannya maupun kelompok lain dengan digunakannya model pembelajaran kooperatif tipe jigsaw adalah sebagai berikut:

Menurut Andra Joevanka Rahmatullah mengatakan bahwa, "saya mengerti dengan materi pembelajaran dikarenakan saya juga ikut bergabung dalam pembuatan materi pembahasan yang telah dijelaskan teman saya".Musyaffa Ahmad Indrakari mengatakan bahwa, "saya lebih banyak tahu daripada sebelumnya dan dari belum tahu menjadi tahu".Sedangkan M. Frans Dewa lanang mengatakan bahwa, "saya mengerti dari pertanyaan-pertanyaan yang dijelaskan teman lebih mendalam dan membuat saya menjadi lebih jelas".

Jadi, berdasarkan hasil wawancara terhadap guru PAI dan siswa kelas VIII-A1 putra SMP-IT Raudhatul Ulum Sakatiga, serta pengamatan peneliti selama berada dilapangan.Maka dapat dikatakan bahwa, dalam hal keceradasan atau intelektual pada diri siswa sesungguhnya berbeda-beda.Akan tetapi, dalam hal memahami mata pelajaran PAI siswa di kelas tersebut cukup baik.Kemandirian itelektual hadir dengan adanya siswa yang bersifat heterogen di dalam lingkungan kelompok pembelajaran, dengan sifat hetereogen maka siswa dapat mengisi kekurangan antara satu dengan yang lainnya.

Secara sederhana dapat dikatakan, siswa yang mempunyai kekurangan dalam hal memecahkan suatu persoalan akan belajar kepada siswa yang mempunyai kelebihan dalam kecerdasan. Dengan kondisi tersebut, secara perlahan akan mempengaruhi pola fikir dan hasil fikiran para siswa untuk bertindak secara cepat dan benar. Selain itu, siswa ketika melakukan interaksi atau hubungan terhadap siswa lainnya maka hal tersebut juga telah menciptakan suatu daya fikir di dalam dirinya untuk ikut berperan serta dalam kelompok, baik dalam hal berdiskusi ataupun memberikan tanggapan dan masukan-masukan yang belum diketahui siswa lainnya. 
Aktivasi Kemandirian Siswa Pada Model Pembelajaran Kooperatif Tipe Jigsaw Dalam Mata Pelajaran PAI di Kelas VIII-A1 Putra SMP IT Raudhatul Ulum Sakatiga

\section{Abdillah Shafrianto}

\section{3) Kemandirian Sosial}

Kemandiran sosial yang berarti kemampuan siswa untuk berinteraksi kepada teman-temannya. "Berdasarakan pengamatan peneliti di kelas VIII-A1 putra SMP-IT Raudhatul Ulum Sakatiga, bahwa untuk kemandirian sosial terlihat cukup baik. Hal tersebut berdasarkan observasi peneliti ketika melihat ketika ada siswa yang bersikap tidak memperhatikan maka ada beberapa siswa yang mengingatkan temannya agar memperhatikan baik dalam penjelasan materi dan jawaban dari pertanyaan kelompok lain. Selain hal tersebut, dalam hal pertanyaan yang belum bisa dijawab maka para siswa berdiskusi dengan kelompoknya untuk mencari jawaban yang tepat dan jika kelompok yang diberikan pertanyaan belum bisa menjawab maka kelompok lain mencoba menjawab pertanyaan tersebut dengan baik". Sedangkan menurut guru PAI yang mengajar dikelas VIII-A1 putra mengatakan bahwa; "Untuk interaksi sosial antar siswa dengan digunakannya model pembelajaran kooperatif tipe jigsaw sangat bagus sekali, dikarenakan ada beberapa siswa yang awalnya pendiam dan pemalu maka kini mereka lebih berani dan aktif dalam berinteraksi".

Adapun untuk dalam hal berinteraksi antar siswa, jika ada siswa yang tidak bisa memahami atau mengerti terhadap materi pelajaran dengan digunakannya model pembelajaran kooperatif tipe jigsaw adalah sebagai berikut:

Menurut Anggara Aziz Auliansyah mengatakan bahwa ketika ia tidak mengerti adalah, "saya bertanya kembali kepada teman yang mempresentasikan materi pembahasan dan membaca buku kembali". M. Akbar Febrianto mengatakan bahwa, "bertanya kepada ustadz dan temanteman, selain itu membaca buku materi kembali". M. Frans Dewa Lanang Mengatakan bahwa, "bertanya kembali kepada kelompok yang memaparkan materinya dan mencari lagi dibuku".

Untuk sikap siswa ketika melihat teman di dalam kelompok ada yang tidak mengerti dengan suatu pembahasan ataupun dengan pertanyaan oleh kelompok lain adalah sebagai berikut:

Andra Joevanka Rahmatullah mengatakan bahwa, "saya langsung membantunya dalam menjelaskan pembahasan yang telah disampaikan".M. Frans Dewa Lanang Mengatakan bahwa, "saya akan menegur teman saya dan juga saya akan menjelaskan kepada teman yang belum mengerti agar lebih faham".M. Akbar Febrianto mengatakan bahwa, "saya akan membantunya dengan memberikan informasi dengan jelas kepada teman yang belum mengerti".Sedangkan Elsa Sarif Hidayatullah mengatakan bahwa, "saya akan menyuruhnya bertanya kepada teman saya yang menjelaskan pembahasan tadi". 
Berdasarkan hasil wawancara yang peneliti lakukan terhadap siswa kelas VIII A1 putra SMP-IT Raudhatul Ulum Sakatiga terhadap teman yang tidak mengerti tentang materi pembahasan atau pertanyaan-pertanyaan dari kelompok lain adalah mereka secara bersama mengatakan bahwa mereka akan ikut membantu siswa ketika ada suatu pembahasan yang tidak mengerti oleh siswa lain dan ikut membantu menjawab. Adapun alasan mereka akan ikut membantu siswa lain adalah sebagai berikut:

Anggara Aziz Auliansyah mengatakan bahwa, "agar teman yang tidak mengerti menjadi mengerti dan bisa memahami lagi untuk materi yang akan datang".Zam Zam Mubarak mengatakan bahwa, "agar teman belum mengerti bisa mengerti dan paham".Miftahul Lazim mengatakan bahwa, "karena kita tidak bisa hidup sendiri, kalau ada teman yang tidak bisa maka harus dibantu".Ahsan Nugraha mengatakan bahwa, "agar teman yang belum mengeri menjadi mengerti". M. Akbar Febrianto mengatakan bahwa, "saya merasa kasihan terhadap teman yang kurang mengerti, percuma bayar mahalmahal disini jika hanya untuk mendapatkan kebodohan".

Dengan demikian, bisa dikatakan bahwa dengan menggunakan model pembelajaran kooperatif tipe jigsaw kepada siswa kelas VIII-A1 putra SMP-IT Raudhatul Ulum Sakatiga dapat memberikan kemandirian kepada para siswa, kemandirian muncul karena disebabkan oleh siswa di dalam model pembelajaran kooperatif tipe jigsaw mempunyai tugas dan fungsi masing-masing.Hal tersebut juga dipertegas oleh guru PAI yang mengajar di kelas VIII-A1 mengatakan bahwa; "Dengan digunakannya model pembelajaran kooperatif tipe jigsaw, tentu memberikan dampak berupa kemandirian kepada para siswa, dikarenakan dengan model pembelajaran tersebut peserta didik akan lebih memiliki arti sebuah tanggung jawab dengan apa yang akan disampaikan kepada teman-temannya".

\section{Faktor yang Menjadi Penghambat dan Pendukung Kemandirian Siswa}

\section{1) Kemandirian Emosi}

Berdasarkan observasi yang peneliti lakukan di kelas VIII-A1 SMP-IT Raudhatul Ulum Sakatiga, "peneliti menjumpai sedikit permasalahan, adapun permasalahannya berupa beberapa siswa yang mengobrol ketika kelompok lain sedang mempresentasikan materi yang dibahas. Selain itu juga ada beberapa siswa yang kurang memperhatikan dan juga ada beberapa siswa yang kurang aktif di dalam kelompok.Untuk siswa yang kurang aktif di dalam kelompok, selama peneliti melakukan observasi yang terlihat adalah siswa atau temannya mencoba membantu untuk memberikan arahan agar siswa yang kurang aktif tersebut untuk bertanya". Dengan demikian, emosi berkaitan dengan sikap siswa yang bersifat negatif yang tercermin dari siswa yang mengobrol dan tidak fokus atau memperhatikan apa yang 
Aktivasi Kemandirian Siswa Pada Model Pembelajaran Kooperatif Tipe Jigsaw Dalam Mata Pelajaran PAI di Kelas VIII-A1 Putra SMP IT Raudhatul Ulum Sakatiga

Abdillah Shafrianto

sedang dibahas oleh kelompok lain. Untuk mengantisipasi siswa yang mempunyai sikap tersebut, guru di dalam kelas menunjukan sikap yang positif terhadap siswa. Adapun cara yang guru gunakan adalah menegur siswa tersebut untuk memperhatikan apa yang sedang dibahas oleh kelompok yang sedang mempresentasikan materinya.

Adapun yang menjadi pendukung dan penghambat perasaan siswa menurut guru PAI yang mengajar dikelas VIII-A1 adalah sebagai berikut;

"Menurut saya yang dapat mendukung perasaan siswa menjadi senang dengan digunakannya pembelajaran kooperatif tipe jigsaw di kelas adalah berupa pemberian reward (penghargaan), pujian dan yang paling penting adalah memberikan motivasi kepada siswa". Sedangkan yang dapat menghambat perasaan siswa menjadi senang di dalam pembelajaran kooperatif adalah, "kurangnya motivasi yang diberikan oleh guru, karena di dalam kegiatan kelompok anak-anak sangat membutuhkan yang namanya motivasi, penghargaan dan pujian.Karena hal demikian dapat meningkatkan semangat dan percaya diri mereka".

Selain itu guru PAI yang mengajar di kelas VIII-A1 juga menambahkan bahwa; "Menurut saya yang mempengaruhi kemandirian emosi siswa dengan digunakannya model pembelajaran kooperatif tipe jigsaw di kelas adalah tidak setiap siswa dapat merasa senang dengan dengan temannya di dalam satu kelompok, seperti siswa yang tidak terlalu banyak memberikan kontribusi pada kelompoknya, biasanya mereka diabaikan oleh teman-teman yang dirasakan mampu. Akan tetapi saya mengarahkan serta mendorong mereka untuk saling membantu dan secara bertahap perubahan emosi pada siswa dapat terlihat dengan baik".

Dengan demikian, berdasarkan hasil wawancara di atas maka dapat dikatakan bahwa yang membuat perasaan siswa menjadi senang dengan menggunakan model pembeajaran kooperatif tipe jigsaw di kelas adalah penghargaan, pujian dan motivasi yang langsung diberikan oleh guru di kelas ketika siswa dapat memecahkan permasalahan selama proses pembelajaran berlangsung. Selain itu, penghargaan kepada siswa dapat menumbuhkan rasa percaya diri, percaya diri untuk menguasai pelajaran ataupun melakukan aktivitas belajar.Siswa dapat menunjukkan rasa percaya diri ketika saat mengajukan pertanyaan baik kepada guru ataupun kepada temannya tanpa perlu takut melakukan kesalahan.Sedangkan yang dapat menghambat perasaan siswa menjadi senang berupa kurangnya motivasi yang diberikan oleh guru, karena siswa sangat membutuhkan motivasi agar mereka dapat belajar dengan giat. 
Volume 2 Nomor 1 Edisi Juni 2017

P-ISSN : 2541-3686

2) Kemandirian Intelektual

Adapun kemandirian intelektual siswa di kelas VIII-A1 putra SMP-IT Raudhatul Ulum Sakatiga, berdasarkan pengamatan yang peneliti lakukan selama berada di lapangan adalah, "ketika siswa mempunyai suatu permasalahan di dalam kelompok yang belum terpecahkan, maka siswa di dalam kelompok memulainya dengan berdiskusi tentang suatu problem tersebut dalam rangka mencari dan memberikan jawaban yang tepat sebagai hasil daripada masalah yang belum terpecahkan. Selain itu juga, ada kelompok lain yang mencoba untuk membantu dalam memberikan jawaban ketika kelompok yang diberikan pertanyaan belum bisa menjawab".

Berdasarkan hal di atas, maka dapat dipahami bahwa setiap perbedaan dalam hal itelektual siswa memberikan warna di dalam kelas, seperti ada siswa yang dapat mengerti dengan cepat apa yang kelompok lain berikan dan ada pula siswa yang lambat menerima pelajaran. Perbedaan kemampuan siswa dapat dilihat melalui pertanyaan yang diajukan dan jawaban yang siswa berikan pada diskusi kelompok.Oleh sebab itu, setiap siswa memiliki intelektual yang berbeda, dalam perbedaan itu bisa dirasakan adanya kesulitan untuk mengetahui ukuran yang tepat mengenai intelektual siswa.Dikarenakan semuanya dipengaruhi oleh lingkungan dalam bentuk pengalaman yang siswa peroleh selama hidupnya.Intelektual pada diri setiap siswa merupakan pembawaan yang diwariskan dan pertumbuhan serta perkembangannya dipengaruhi oleh lingkungan, sebagai kekuatan yang tidak bisa dipisahkan dari kehidupan siswa.

Adapun yang menjadi pendukung dan pengambat siswa untuk mengerti terhadap materi pembelajaran menurut guru PAI yang mengajar di kelas VIII-A1 adalah sebagai berikut;

"Menurut saya yang dapat mendukung siswa menjadi mengerti pada materi pembelajaran dengan digunakannya model pembelajaran kooperatif tipe jigsaw adalah dengan memberikan arahan dan gambaran tentang permasalahan atau tentang materi yang akan disampaikan.Sehingga siswa dapat menyampaikan materi kepada teman-temannya dengan baik, dengan memberikan gambaran dan arahan maka siswa mampu atau dapat dikatakan bisa memahami pokok materi yang dipelajari".Sedangkan yang dapat menghambat siswa menjadi mengerti menurut saya, "berupa kurangnya informasi, komunikasi dan keaktifan guru dalam memberikan tugas serta kegiatan siswa di dalam kelompok".

Selain itu guru PAI yang mengajar di kelas VIII-A1 juga menambahkan bahwa;

"Menurut saya, dalam model pembelajaran kooperatif tipe jigsaw ini yang menjadi pengaruh kemandirian intelektual adalah hubungan akrab antara guru dan siswa. Karena dengan adanya hubungan yang akrab, secara kejiwaan siswa akan merasa aman sehingga masalah yang dialami pada proses pembelajaran dapat dikonsultasikan kepada guru. Lain halnya jika siswa 
Aktivasi Kemandirian Siswa Pada Model Pembelajaran Kooperatif Tipe Jigsaw Dalam Mata Pelajaran PAI di Kelas VIII-A1 Putra SMP IT Raudhatul Ulum Sakatiga

Abdillah Shafrianto

merasa takut kepada guru, mereka tidak akan berani untuk memberitahukan kepada guru apa yang menghambat mereka untuk mengerti dan bagaimana cara mengatasi masalah dengan suatu materi pembelajaran".

Berdasarkan wawancara peneliti dengan guru PAI yang mengajar di kelas VIIIA1 di atas, dapat dikatakan bahwa yang dapat mendukung siswa menjadi mengerti atau paham dengan materi pelajaran ketika menggunakan model pembelajaran kooperatif tipe jigsaw adalah pemberian arahan atau penyampaian materi yang dilakukan oleh guru dengan baik dan benar. Dengan pengarahan dan pemberian materi yang benar, maka siswa akan lebih mudah untuk dapat memahami dan mengerti tentang materi yang mereka bahas secara berkelompok. Sedangkan yang dapat menghambat siswa untuk mengerti dengan materi pembelajaran dengan digunakannya model pembelajaran koopertif tipe jigsaw adalah kurangnya pemberian informasi dari guru kepada siswa, komunikasi dan keaktifan guru itu sendiri kepada siswa selama proses pembelajaran sedang berlangsung.

\section{3) Kemandirian Sosial}

Ada beberapa hal yang ikut serta mempengaruhi kemandirian sosial siswa di kelas VIII-A1 putra SMP-IT Raudhatul Ulum Sakatiga berdasarkan hasil pengamatan yang peneliti lakukan selama berada di lapangan atau tempat penelitian antara lain adalah; "Pertama, keterbukaan dalam komunikasi interpersonal. Maksudnya disini adalah keterbukaan diri siswa karena suatu keadaan, contohnya seperti siswa yang tidak mengerti tentang materi pembahasan maka ia akan memberitahu kepada temannya baik secara pribadi ataupun kelompok bahwa ia tidak mengerti tentang materi tersebut. Kedua, rasa empati siswa terhadap teman yang tidak mengerti terhadap materi pembahasan.Ketiga, keadaan yang mendukung maksudnya disini adalah dukungan sesama siswa di dalam kelompok.Keempat, sikap yang positif dalam berkomunikasi sesama siswa.Maksudnya adalah sikap terhadap teman-teman yang belum mengerti di dalam materi pembahasan.Kelima, kesamaan tentang tujuan, maksudnya disini adalah siswa dalam pembelajaran kooperatif harus mempunyai tujuan yang sama yang berarti bahwa siswa dalam pembahasan materi harus mempunyai tujuan yang sama jika ingin kelompoknya berhasil".

Adapun yang menjadi pendukung dan penghambat pada interaksi sosial siswa menurut guru PAI yang mengajar di kelas VIII-A1 adalah sebagai berikut;

"Menurut saya yang dapat mendukung interaksi sosial siswa dengan digunakannya model pembelajaran kooperaif tipe jigsaw adalah materi yang dipelajari siswa itu sendiri. Karena dengan materi yang telah dipersiapkan dengan baik, maka siswa dengan sendirinya akan berinteraksi untuk melakukan tanya jawab atau berdiskusi untuk membahas permasalahan di dalam materi tersebut. Sedangkan yang dapat menghambat interaksi sosial di dalam model pembelajaran kooperatif tipe jigsaw menurut saya adalah tidak 
adanya materi, karena dengan tidak adanya materi maka secara otomatis siswa akan bingung dalam berinteraksi di dalam kelompoknya".Selain itu, "menurut saya yang menjadi penghambat siswa dalam berinteraksi adalah pengelompokan siswa, jika siswa dikelompokan tidak bersifat heterogen maka siswa akan kesulitan dalam berdiskusi karena tidak adanya siswa yang mencoba untuk memecahkan masalah".

Selain itu menurut guru PAI yang mengajar di kelas VII-A1 megatakan bahwa; "Menurut saya, yang menjadi pengaruh kemandirian sosial siswa dengan digunakannya model pembelajaran kooperatif tipe jigsaw adalah empati siswa terhadap sesama mereka, karena di dalam jigsaw siswa dikelompokan berdasarkan karakteristik yang berbeda-beda baik berupa kecerdasan dan lain sebagainya. Hal tersebut membuat siswa mempunyai rasa empati untuk membantu siswa lain ketika ada masalah ataupun ada materi yang tidak dipahami. Selain itu menurut saya adalah kelompok biasanya hanya terfokus kepada satu bagian materi saja, seperti pembagian materi yang berbeda antara kelompok satu dengan lainnya, hal ini menyebabkan kelompok lain tidak perduli pada materi kelompok lainnya, padahal antara satu materi dengan materi lainnya saling berhubungan. Untuk mengatasi sebelum hal tersebut terjadi, yang saya lakukan adalah dengan memberikan penjelasan dan arahan materi yang baik dan lengkap kepada kelompok ahli, agar kelompok ahli dapat memberikan penjelasan materi secara keseluruhan kepada kelompok asal".

Berdasarkan hasil wawancara peneliti dengan guru PAI yang mengajar di kelas VIII-A1 di atas, maka dapat dikatakan bahwa yang dapat menjadi pendukung interaksi sosial siswa dengan digunakannya model pembelajaran kooperatif tipe jigsaw adalah materi pembelajaran yang telah dipersiapkan atau direncanakan oleh guru dengan baik. Karena dengan adanya materi yang dipersiapkan dengan baik, maka siswa akan menjadi aktif untuk berdiskusi, saling membantu dalam menyelesaikan permasalahan dan saling bermusyawarah akan pendapat masingmasing. Sedangkan yang dapat menghambat interaksi sosial siswa dengan digunakannya model pembelajaran kooperatif tipe jigsaw adalah tidak dipersiapkannya materi pembelajaran dengan baik, jika tidak materi pembelajaran tidak dipersiapkan dengan baik maka siswa akan menjadi sulit untuk berdiskusi dikarenakan tidak adanya bahan yang membuat siswa untuk saling berbagi.

\section{Simpulan}

Berdasarkan hasil yang diperoleh melalui penelitian ini dapat disimpukan sebagai berikut:

1. Adapun pelaksanaan model pembelajaran kooperatif tipe jigsaw di kelas VIIIA1 SMP-IT Raudhatul Ulum Sakatiga adalah sangat baik dan tanpa kendala yang berarti, dikarenakan siswa dan guru yang mengajar di kelas tersebut terlibat aktif dalam proses pembelajaran. 
Aktivasi Kemandirian Siswa Pada Model Pembelajaran Kooperatif Tipe Jigsaw Dalam Mata Pelajaran PAI di Kelas VIII-A1 Putra SMP IT Raudhatul Ulum Sakatiga

\section{Abdillah Shafrianto}

2. Untuk kemandirian siswa di kelas VIII-A1 baik berupa kemandirian emosi, intelektual dan sosial juga sangat baik, hal tersebut berdasarkan pada perasaan siswa yang senang dengan materi dan teman-teman di dalam kelompok, siswa mengerti dengan materi pembelajaran yang disampaikan dan juga siswa saling membantu ketika ada permasalahan dengan materi pembelajaran. Model pembelajaran kooperatif tipe jigsaw dapat membuat siswa menjadi mandiri karena adanya kerja sama siswa, saling membantu dan saling berempati di dalam model pembelajaran tersebut.

3. Pada pembelajaran kooperatif tipe jigsaw ada faktor-faktor terhadap kemandirian siswa seperti:

1) Reward (penghargaan), pujian, motivasi yang diberikan oleh guru dan kontribusi anggota kepada kelompoknya

2) Pemberian informasi, arahan terhadap materi yang baik kepada siswa dan hubungan akrab antara guru dengan siswa

3) Materi pembelajaran yang telah direncanakan dan dipersiapkan oleh guru dengan baik untuk dipelajari siswa dan pengelompokkan siswa yang dibuat oleh guru berdasarkan karakteristik siswa yang berbeda seperti tingkat kecerdasan dan interaksi sosialnya, serta rasa empati terhadap sesama teman di dalam kelompoknya 


\section{DAFTAR PUSTAKA}

Ali, Mohammad \& Asrori,Mohammad.,Psikologi Remaja Perkembangan Peserta Didik, Jakarta: Bumi Aksara, 2014.

Arikunto, Suharsimi.,Manajemen Penelitian, Jakarta: Rineka Cipta, 2010.

Daradjat, Zakiah t et al., Ilmu Pendidikan islam, Jakarta: Bumi Aksara, 2011.

Desmita., Psikologi Perkembangan Peserta Didik, Bandung: Rosdakarya, 2014.

Fatimah, Enung., Psikolog Perkembangan; Perkembangan Peserta Didik,Bandung: Pustaka Setia, 2010.

Hidayat, Ara \&Imam ,Machali., Pengelolaan Pendidikan, Yogyakarta: Kaukaba 2012.

Husamah.,Kamus Psikologi Super Lengkap, Yogyakarta: Andi, 2015.

Moleong, Lexy J.., Metodologi Penelitian Kualitatif, Bandung: Rosda Karya, 2014.

Morrison. S, George., Dasar-Dasar Pendidikan Anak Usia Dini (PAUD), Jakarta: PT Indeks, 2012.

Nasution.,Metode Research, Jakarta: Bumi Aksara, 2012.

Nasution.,Sosiologi Pendidikan, Jakarta: Bumi Aksara, 2014.

Sedarmayanti \& hidayat, Syarifudin.,Metodologi Penelitian, Bandung: Mandar maju, 2011.

Rusman., Model-Model Pembelajaran Mengembangkan Profesionalisme Guru, Jakarta: Rajawali Pers, 2014.

Slameto.,Belajar dan Faktor-Faktor Yang Mempengaruhi, Jakarta: Rineka Cipta, 2013.

Sopiah, Dwi Istiyani, Nur Khasanah, Perempuan dan Pendidikan Tinggi, Pekalongan, STAIN Press, 2014.

Sudjana, Nana.,Penelitian dan Penilaian Pendidikan, Bandung: Sinar Baru Algensindo, 2012

Sugiyono.,Metode Penelitian Kuantitatif Kualitatif Dan RED, Bandung: Alfabeta, 2013. Syah ,Muhibbin., Psikologi Pendidikan Dengan Pendekatan Baru, Bandung: PT Remaja Rosda Karya, 2008.

Syah ,Muhibbin., Psikologi Belajar, Jakarta: Raja Grafindo Persada, 2013.

Tirto, Negoro Suratino., Kecenderungan Hidup Mandiri, Bandung: Tarsito, 2008.

Urniasih, Imas K \&Sani,Berli.,Ragam Pengembangan Model pembelajaran Untuk Meningkatkan Profesionalitas Guru, Yogyakarta: Kata Pena, 2015 
Aktivasi Kemandirian Siswa Pada Model Pembelajaran Kooperatif Tipe Jigsaw Dalam Mata Pelajaran PAI di Kelas VIII-A1 Putra SMP IT Raudhatul Ulum Sakatiga

Abdillah Shafrianto 